\title{
Investigating Performance of Plastic Hinge in Steel Frames by Knee Bracing
}

\section{Behzad Dezhkam}

Faculty member of Civil Engineering University of velayat, Iranshahr, IRAN.

\begin{abstract}
Constructing plastic hinges and the way of their distribution and failure mechanism can play an important role on seismic structures design. Mechanism type affect frame sensitivity toward secondary effects, total and local ductility, energy absorption and structure resistance before damage, general instability and destruction. Failure mechanism of moment frames under earthquake effect could be mentioned as three general types (first, second and third). The first type resulted from constructing hinges in beams and columns in the first few -story up, the second one resulted from constructing hinges in beams and columns of few upper -story and the third type including mechanism of one middle floor. Failure mechanism of general type is a special mode of the second type mechanism in which, plastic hinges locating at the two ends of beams and the first floor columns near the connection to the foundation. Based on researches, this type of mechanism shows the most amount of energy absorption against earth quack. Knee bracing frame is appropriate as an energy dissipation system composed of ductility and lateral stiffness which has good performance against lateral loads specially earthquake. In this paper, forming plastic hinges of components and the base shear of different steel systems and comparing them with knee bracing lateral load system in three, five and seven -story frames using regulations of FEMA356 and ATC-40.
\end{abstract}

KEYWORDS

Plastic hinge, Steel frames, Knee bracing
ARTICLE HISTORY

Received 6 November 2016

Revised 14 March 2017

Accepted 22 March 2017

\section{Introduction}

Analyzed frames including moment frames, normal frames with chevron bracing, knee bracing, $\mathrm{x}$ bracing in three levels which are 3--story, 5--story and 7--story and three and five 5-meter -bay have been evaluated. -story height of all models has considered 3 meters. Allowable stress of steel materials is 2400 , CORRESPONDENCE Behzad Dejkam $\square$ behzaddejkam@yahoo.com

(C) 2017 Dejkam

Open Access terms of the Creative Commons Attribution 4.0 International License apply. The license permits unrestricted use, distribution, and reproduction in any medium, on the condition that users give exact credit to the original author(s) and the source, provide a link to the Creative Commons license, and indicate if they made any changes. (http://creativecommons.org/licenses/by/4.0/) 
ultimate stress is 3700 , expected yielding strength of this steel is 2640 and ultimate expected strength is 4070 . Structures are designed according to the UBC97, $6^{\text {th }}$ code is used for gravity loading and 2800 code for lateral loading. Dead load for all -story is 550, live load for -story is 200 and for roof is 150 has been considered. The load width for these frames is assumed 3 meters.

Table 1. For simplifying, equivalent terms are used for each models.

\begin{tabular}{|c|c|}
\hline $\begin{array}{l}3 \text {-story, } 3 \text {-bay with } \mathrm{x} \text { bracing model (X- } \\
\text { brace } 3 \mathrm{St}-3 \mathrm{~B} \text { ) }\end{array}$ & $\begin{array}{l}5 \text {-story, } 3 \text {-bay with knee bracing } \\
\text { model (Knee 5St-3B) }\end{array}$ \\
\hline $\begin{array}{l}3 \text {-story, } 3 \text {-bay with knee bracing model } \\
\text { (Knee 3St-3B) }\end{array}$ & $\begin{array}{l}5 \text {-story, } 3 \text {-bay with chevron bracing } \\
\text { model (Chevron 5St-3B) }\end{array}$ \\
\hline $\begin{array}{l}3 \text {-story, } 3 \text {-bay with chevron model } \\
\text { (Chevron 3St-3B) }\end{array}$ & $\begin{array}{l}7 \text {-story, } 3 \text {-bay with } \mathrm{x} \text { bracing model } \\
\text { (X-brace 7St-3B) }\end{array}$ \\
\hline $\begin{array}{l}3 \text {-story, } 3 \text {-bay , Moment model (M 3St- } \\
\text { 3B) }\end{array}$ & $\begin{array}{l}7 \text {-story, } 3 \text {-bay with knee bracing } \\
\text { model (Knee-brace 7St-3B) }\end{array}$ \\
\hline $\begin{array}{l}5 \text {-story, } 3 \text {-bay with } \mathrm{x} \text { bracing model (X- } \\
\text { brace } 5 \mathrm{St}-3 \mathrm{~B} \text { ) }\end{array}$ & $\begin{array}{l}7 \text {-story, } 3 \text {-bay with knee bracing } \\
\text { model (Knee } 7 \text { St-3B) }\end{array}$ \\
\hline $\begin{array}{l}5 \text {-story, } 3 \text {-bay with knee bracing model } \\
\text { (Knee-brace } 5 \text { St-3B) }\end{array}$ & $\begin{array}{l}7 \text {-story, } 3 \text {-bay with knee bracing } \\
\text { model (Chevron 7St-3B) }\end{array}$ \\
\hline
\end{tabular}

5--story models has been determined like 3 -story models with one difference, 3B has been changed to $5 \mathrm{~B}$.

For primary analysis and design of frames, ETABS and for seismic evaluation with non-linear static analysis SAP 2000 have been used. In designing models, the status of joints will be as follows: beam-column joints in the form of rigid, joints of the knee element to beam and column in the form of rigid, joints of diagonal bracing to the knee element and to the column as well as the joint of column leg as hinge. Knee elements has been designed considering moment yielding, so Eq.1 should be satisfied in all knee elements.

1)

Where:

The least length of knee element, = section plastic moment, $=$ section plastic shear

To compute, Eq.2 and Eq.3 have been used.

Where: 
$\mathrm{Z}=$ plastic section modulus,$=$ steel yield stress, $=$ web thickness, $=$ flange thickness, $d=$ section height

For example, knee calculation with section $\operatorname{HSS} 4 \times 4 \times 1 / 2$ has been showed.

\section{Knee bracing situation}

According to the experiments taken in previous investigations the best angle to install knee element is parallel to diagonal bracing, so is considered. (fig1) also it is recommended to consider. To simplify the model and based on the indicated limitations, all knees has been considered with $115 \mathrm{~cm}$ length, $\mathrm{h}=60 \mathrm{~cm}$ and $\mathrm{b}=$ $100 \mathrm{~cm}$.

\section{B}

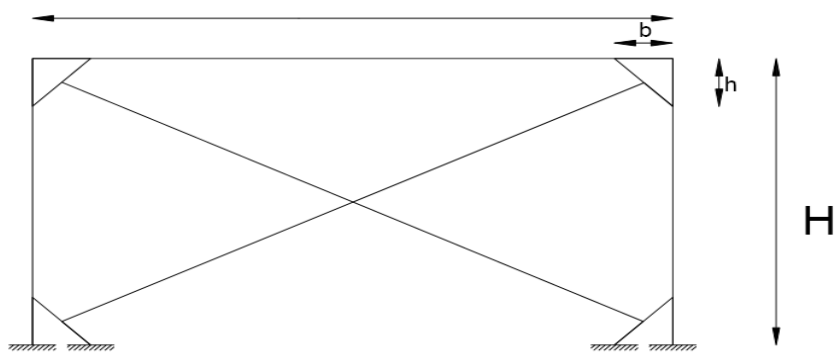

Figure 1. Diagonal knee braced frame (KBF)

\section{Plastic hinge properties introduction}

In non-linear static analysis, plastic hinge properties should be related to structures elements. [12] In this level, because two ends of beams in braced frames are hinge, plastic hinges is allocated to middle of beams because of their possibility to develop. In columns, this plastic hinges has been determined in ends of columns that is similar to fact.

Plastic hinges of axial forces in middle of bracings have considered cording to ultimate compressive strength. Also for knee elements, according to consideration of their moment behavior, moment plastic hinges has considered in start, middle and end on knee element. Because plastic hinges in steel structures approximately spread to a length as long as section depth and in SAP 2000 plastic hinges is determined as point, so possible point for development of plastic hinges has been considered in $0.05 \mathrm{~L}$ and 0.95 for columns.

In non-linear static method, instead of experiment or analysis results, it is allowed to use force-deformation curve given in figure 2 with $\mathrm{a}, \mathrm{b}$ and $\mathrm{c}$ determined in FEMA356 for steel frames. Also rotation or deformation corresponding to different levels of performance in elements which are controlled by deformation is introduced in this table. Slope of strain stiffening effects is considered Equivalent to 3\% of elastic slope. Considering higher slope for strain stiffening part, only is allowed in experiments that is not evaluated in this investigation. Q and parameters in fig3 shows generalized force and strength of first yielding of element, respectively. In beams and columns, $\theta$ means all elastic 
and plastic rotation of beam or column, $\theta \mathrm{y}$ yielding rotation, $\Delta$ all elastic and plastic deformation and $\Delta y$ yielding deformation. Also fig3 indicates rotation of the line between end and start of beam.
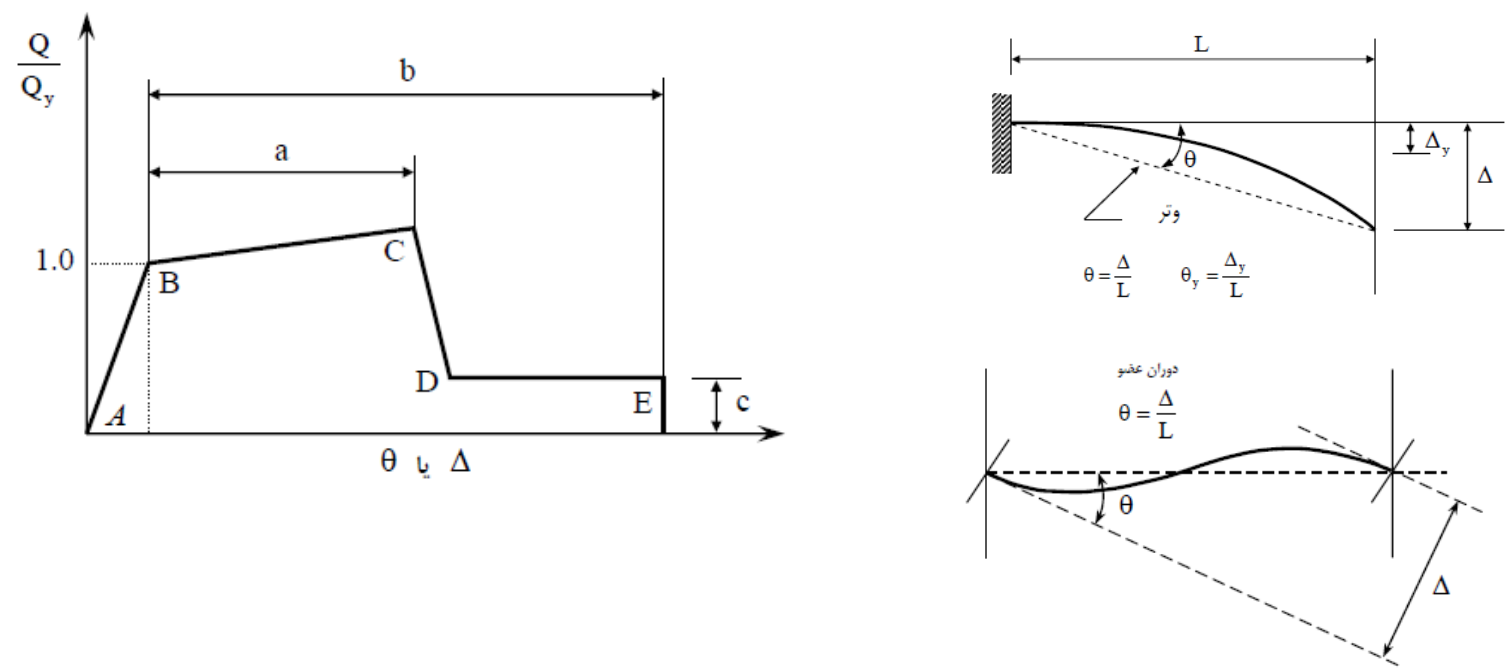

Figure 2. Force-deformation curve for steel members

Fig3. Element rotation definition

In beams and column, $\theta \mathrm{y}$ is calculated by Eq4 and Eq5 respectively.

$$
\begin{aligned}
& \theta_{\mathrm{y}}=\mathrm{ZF}_{\mathrm{ye}} \mathrm{Lb}_{\mathrm{b}} / 6 \mathrm{EI}_{\mathrm{b}} \\
& \theta_{\mathrm{y}}=\mathrm{ZF}_{\mathrm{ye}} \mathrm{L}_{\mathrm{c}} / 6 \mathrm{EI}_{\mathrm{c}}\left[1-\mathrm{P} / \mathrm{P}_{\text {ye }}\right]
\end{aligned}
$$

Where:

$\mathrm{E}=$ Modulus of Elasticity, = expected stress for element yielding, I= Moment of inertia, = Beam Length, = Column length, $\mathrm{P}=$ axial force of element is goal deformation,

$=$ expected axial force for element yielding

For defining plastic hinges in beams and columns, slender restrictions have an important role in level of performance definition and section plastic strength. This issue induce plastic hinges not to be chosen automatically by the software. So for all used sections in this investigation, plastic rotation values is calculated and their parameter is allocated to plastic hinges by FEMA 356 requirements. Seismic parameters is obtained ACCORDING TO IRANIAN 2800 STANDARD for soil type II and area with high seismicity $(\mathrm{A}=0.3)$ 
According to the FEMA 356 and improvement manual, improvement levels are depended on level of performance and seismic danger. Response spectrum design is considered on level of seismic danger 1 that is considered for design in IRANIAN 2800 STANDARD

\section{Evaluation with non-linear static analysis}

Because of the simplicity, non-linear static methods are one of most common analysis tools and they indicated an effective graphic show from general structure response by pushover curve. this curve is directly related to system capacity that is usually defined by base shear with the response of a very significant structural node (control node). This kind of general response of structure allows to directly idealize from structure as single degree of freedom that really simplify design and evaluation. in this part, non-linear static analysis is used to compare mentioned bracings for evaluating system capacity, safety factor, maximum relative displacement in -story and also maximum shear created in -story.

\section{Lateral load distribution}

As recommended for structures improvement in 360 magazine, lateral load distribution should be similar to what happens in earthquake. So at least two kinds of lateral load distribution should apply to structure. In this part a distribution corresponding to the first mode of vibration in the desired direction as the first pattern of lateral load has been utilized. Uniform load distribution in structure height is used for second load combination.

\section{applying gravity load}

While evaluating structure against lateral loads, It should be considered to apply lateral load and gravity load simultaneously, so first structure against gravity loads should be analyzed with non-linear method, then, lateral loads applies to structure while gravity loads exists. According to available buildings improvement manual, high and low limit of gravity load effects (QG) is calculated by following equations.

$$
Q_{G}=1.1\left(Q_{D}+Q_{L}\right)
$$

$$
Q_{G}=0.9 Q_{D}
$$

Where:

\section{Investigating the base shear}

Nonlinear statistic procedure (NSP) accepted in this regulation is a Capacity spectrum method proposed by Freeman (1994) (Ghodrati and Eghbali, 2010). This method has an approach similar to the most pushovers' methods of equal linearization and estimate the maximum total displacement of structure 
through graphical repeat procedure. After doing pushover analyze, changing target place (performance point) will achieved by capacity spectrum method proposed in regulation of ATC- 40 .

Figure 4 shows the base shear results in target displacement point for evaluated structures under load pattern of the first mode. Total trend in figure4 show that structures had higher primary stiffness, tolerate greater base shear in target displacement point. However, this trend had not been created in some modes as could be seen in this figure for $\mathrm{X}$ braces. This can be resulted by deconstruction of some part of structure before reaching target displacement point. So, the base shear has a little amount. Also, considering this figure it can be concluded that the total trend and total behavior of structures for three and 5--bay are the same.

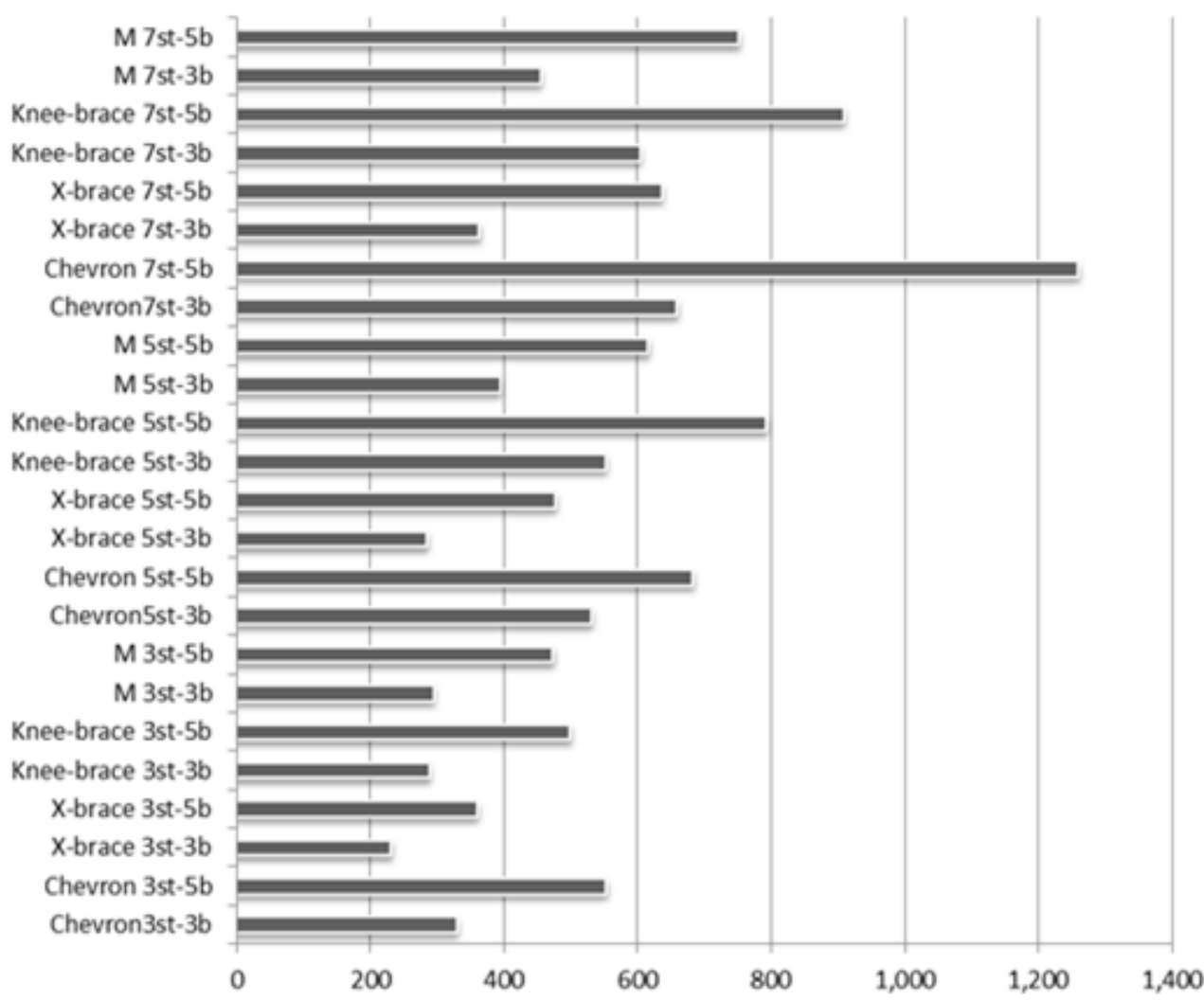

Figure 4. Diagram of the base shear in target displacement for different structures in the load pattern according to the first model of vibration

Figure 5 shows results of the base shear in target displacement point for evaluated systems under uniform load pattern. As it can be seen, total results and structure behavior resulted from structure analysis under different evaluated loading patterns are the same. But achieved results under uniform load pattern predict higher amounts. Generally, the less base shear in these figures show this point that structure has softer behavior against lateral load 
and has more ductility and can have more power pf energy absorption as it can be seen in moment structures. On the other hand, this understanding can not be certain as in Chevron bracing structures, little amounts of base shear were seen while these structures have not much power of energy absorption and lateral loading capacity over the other bracings.

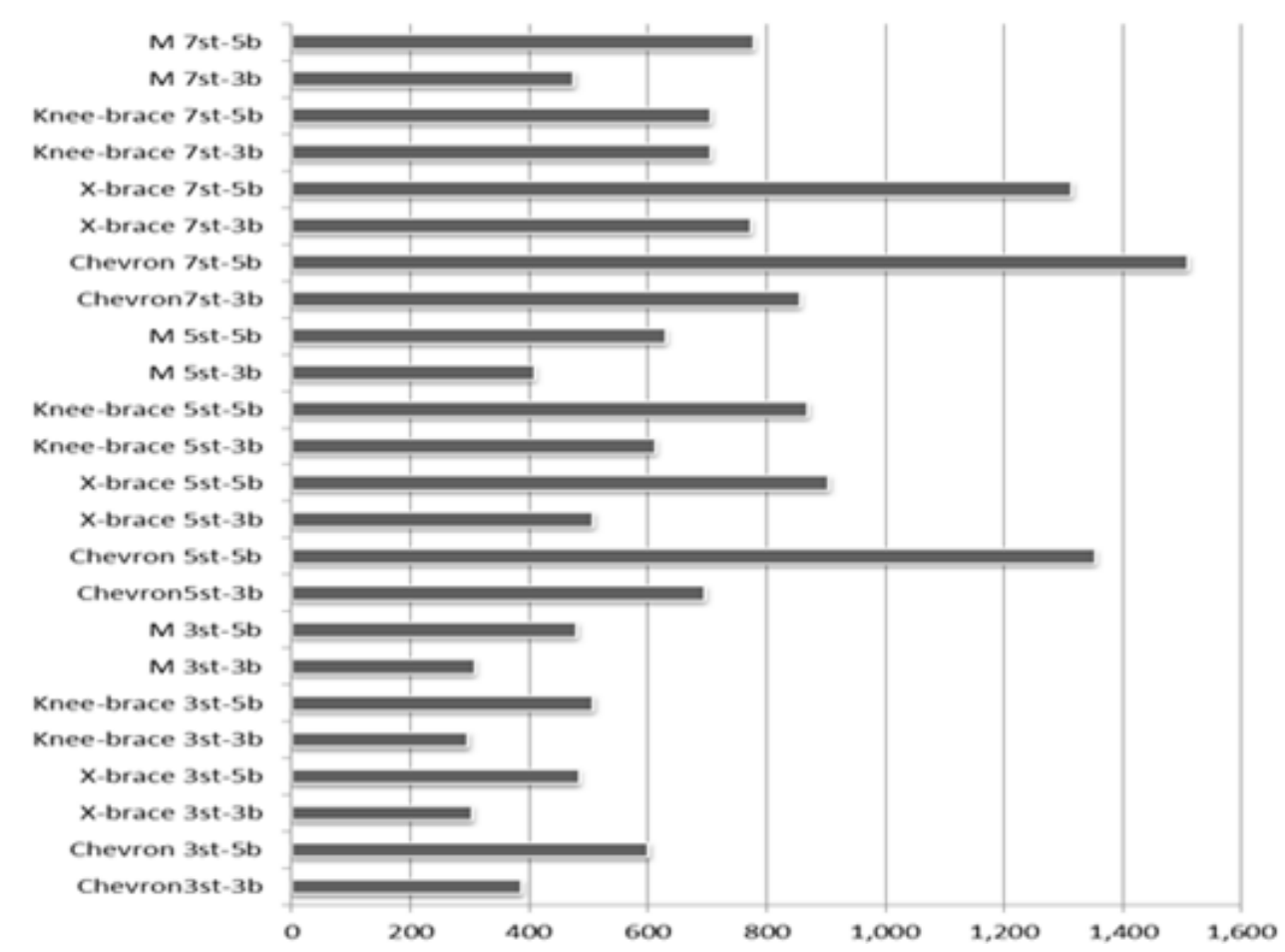

Figure 5. The base shear figure in target displacement for different structures in uniform load pattern

By comparing diagrams of 4 and 5 figures it could be said that structure capacity greatly being decreased by forming soft -story . As seen, structures with knee braces has greater capacity of ductility and as a result, could be designed by fewer base shear, causes saving in steel consumption. Also, this type of structure decreases -story drift with keeping ductility. Considering results, three--story, three --bay with knee bracing under the load pattern of the first mode has $17 \%$ decrease compared to the uniform load pattern; three--story, five--bay under modulus load pattern has $10 \%$ decrease compared to the uniform load pattern which shows the more number of knee component, the more will be the energy absorption and the less will be the base shear. But three--bay five -story with knee bracing under the first mode load pattern has 19\% decrease compared to the uniform load pattern. Five -story with five -bay under modulus load pattern of vibration has $3 \%$ decrease compared to the uniform load. In three--bay seven story with knee bracing under the first mode load pattern has 36\% decrease compared to the uniform load pattern. Five--bay seven -story under vibration modulus load pattern shows $9 \%$ decrease compared to the uniform load pattern. Also, it is seen that three -story of knee bracing has $8 \%$ decrease compared to 
the moment frames of three -story but three -story with knee bracing has $10 \%$ increase compared to the three -story with Chevron frames and 13\% increase compared to the three -story with coaxial bracing. Also, it is seen that five -story of knee bracing has $12 \%$ decrease compared to the moment frames of five -story but five -story with knee bracing has 11\% decrease compared to the five -story with Chevron frames and has 5\% increase compared to the five -story with coaxial bracing. But, in seven -story of knee bracing has $2 \%$ decrease compared to the seven -story of moment frame but seven -story with knee bracing has $26 \%$ decrease compared to the seven -story with Chevron frame and 7\% increase compared to the coaxial bracing. Structures with knee bracing has increasing in the base shear in height. Also it is seen that structures with knee bracing under uniform load pattern experience more base shear vibration compared to the structures with knee bracing under the first mode of load pattern. Additionally, it is seen that in five--bay structures compared to the three--bay structures has decrease in the base shear because of having a knee member which is show that the more knee member has more energy absorption which cause decrease in the base shear.

\section{Evaluating members performance in steel frames}

Investigating members in steel frames by sap2000 software was done in the risk level of life safety which was calculated considering hinges definitions according to the FEMA356 regulation and it is defined for each members of column, beam, bracing and knee member. In this section, we investigate members of three, five and seven--story models in two types of three and five--bay. In figure (6-A) performance level shows three--bay three -story frames with knee bracings. Considering this figure, it can be found that $95 \%$ beam and $100 \%$ column and $82 \%$ diagonal bracing are uninterrupted in the level of service performance. In this frame, $29 \%$ of knee member suffered buckling and loss their performance. But, $41 \%$ bracings are uninterrupted in performance level and $21 \%$ are in performance level of life safety.
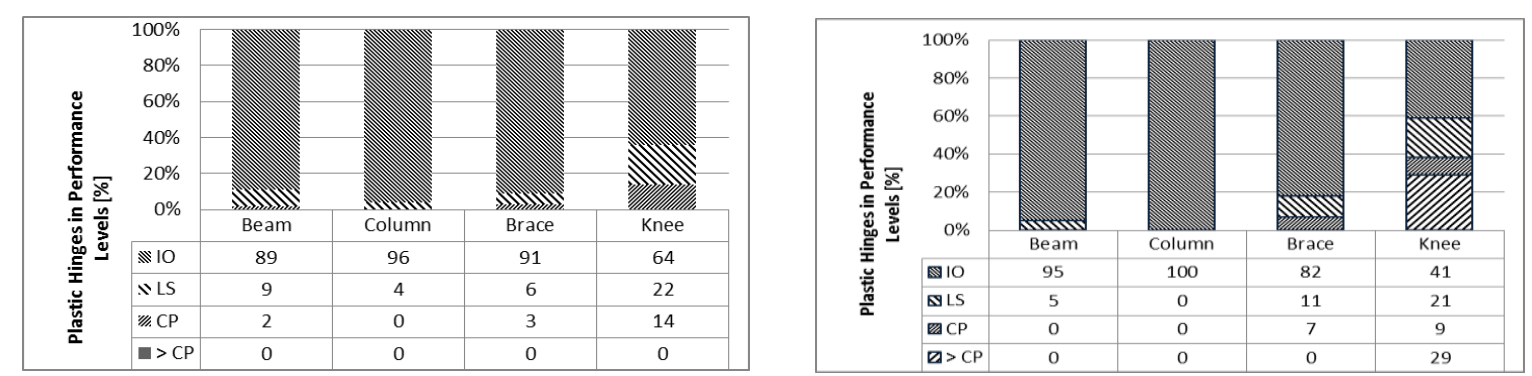

Figure 6. Three--story frame performance level of knee bracing

Figures 7(A) and (B) show performance level of three--story, three -bay frames with Chevron bracings. It is seen that in this structure, $92 \%$ of column is uninterrupted at service performance level but only $8 \%$ is at the performance level of life safety but the beams are uninterrupted at service performance level 
by $88 \%$ and $9 \%$ are at the performance level of life safety and $3 \%$ are on the verge of collapse. For this three--bay structure, $18 \%$ of braces undergone buckling and lost their performance. Figure (7-B) shows performance level of three--story,three -bay frames with Chevron braces, it is seen that in this structure, $97 \%$ of column is uninterrupted at service performance level, only $3 \%$ of it is at the performance level of life safety but $93 \%$ of beams are uninterrupted at service performance level and only $7 \%$ of are at the performance level of life safety. For this frame, beams $97 \%$ are uninterrupted at service performance level and only $5 \%$ are at the performance level of life safety and $19 \%$ undergone buckling and lost their performance.

\begin{tabular}{|c|c|c|c|}
\hline \multirow[t]{2}{*}{$\begin{array}{r}100 \% \\
50 \% \\
0 \%\end{array}$} & & & 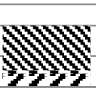 \\
\hline & Beam & Column & Brace \\
\hline \$ 10 & 93 & 97 & 73 \\
\hline $\mathbf{N L S}$ & 7 & 3 & 5 \\
\hline$\not C \mathrm{CP}$ & 0 & 0 & 3 \\
\hline$\Rightarrow>C P$ & 0 & 0 & 19 \\
\hline
\end{tabular}

\begin{tabular}{|c|c|c|c|}
\hline \multirow[t]{2}{*}{$\begin{array}{r}100 \% \\
50 \% \\
0 \%\end{array}$} & & & 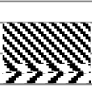 \\
\hline & Beam & Column & Brace \\
\hline$\$ 10$ & 88 & 92 & 67 \\
\hline NLS & 9 & 8 & 12 \\
\hline $\mathscr{Z C P}$ & 3 & 0 & 3 \\
\hline$\geqslant>C P$ & 0 & 0 & 18 \\
\hline
\end{tabular}

Figure7. Performance level of three--story frame with Chevron brace

Figure (8-A) shows performance level of three -story three -bay frames with coaxial bracings. As can be seen, members of $86 \%$ beam and $92 \%$ column are uninterrupted at service performance level. For diagonal bracings, 5\% of them undergone buckling and lost their performance. But $50 \%$ of them are uninterrupted at the service performance level. Figure (8-B) shows performance of three--story, five--bay frames with coaxial bracings. As can be seen, $96 \%$ of beam members and $89 \%$ of column are uninterrupted at the service performance level. For coaxial bracings, $18 \%$ of them undergone buckling and lost their performance. But, $49 \%$ are uninterrupted in the service performance level and $21 \%$ are at the performance level of life safety and $12 \%$ are on the verge of collapse.
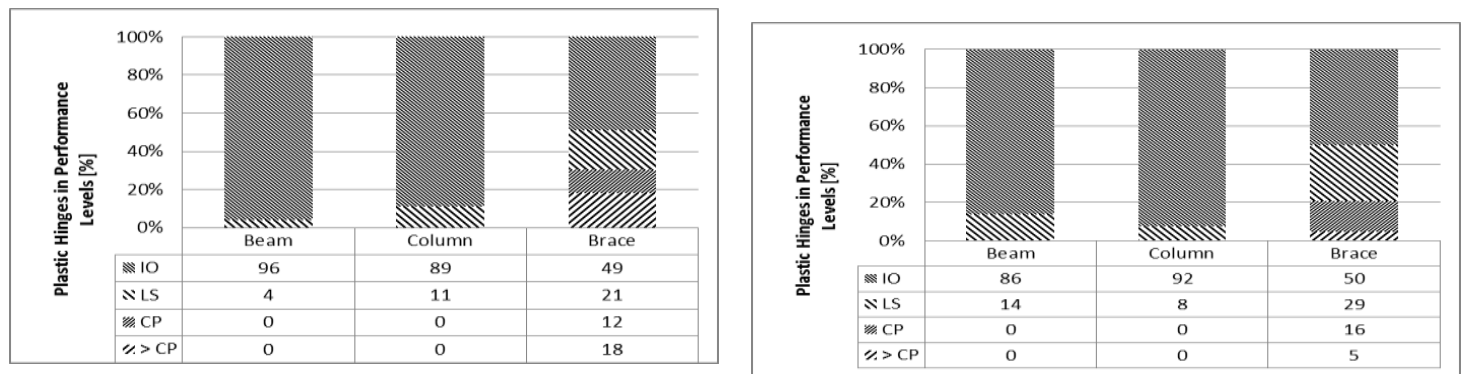

Figure 8. Performance level of three--story frame with coaxial bracing

Figures (9-A) and (9-B) show performance level of moment three -story frames. In three--bay structure, $96 \%$ of members and in five--bay structures, $100 \%$ of column are uninterrupted in service performance level. $80 \%$ of beam members in three--bay and $85 \%$ of beam members in five--bay locate in performance level of 
uninterrupted service and all hinges participated in lateral loading and only $8 \%$ of beam members and $3 \%$ of beam in five -bay are on the verge of collapse.
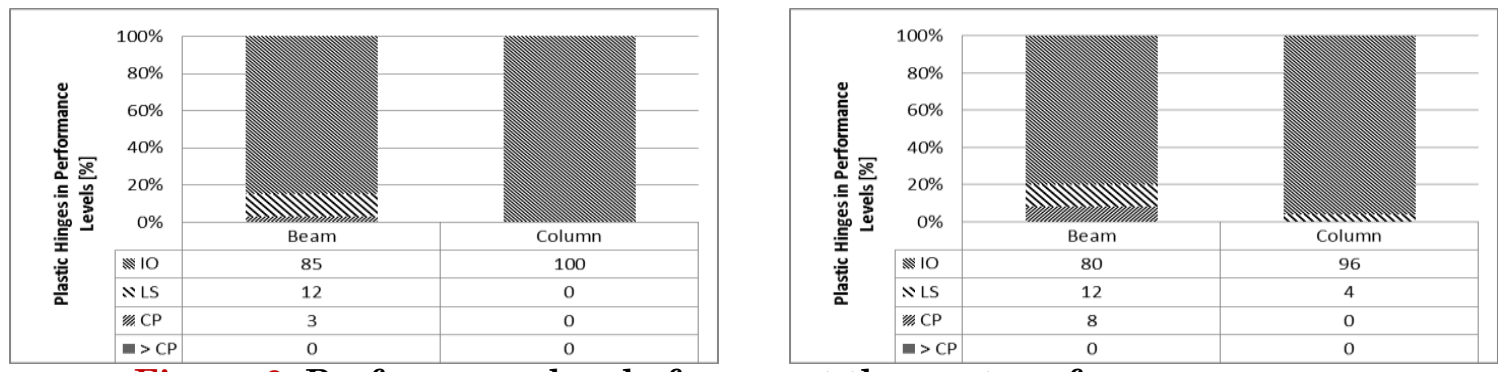

Figure 9. Performance level of moment three -story frame

Figures (10-A) and (10-B) show performance level of five -story frames with knee bracings. In this structure, $91 \%$ of beam members, $100 \%$ of column and $89 \%$ of coaxial bracing members are at the performance level of uninterrupted service. Knee member for three -bay are at the performance level of uninterrupted service in $77 \%$ of cases and $11 \%$ undergone destruction. Also, it is seen that at the five -bay frame, bracings in five-bay are uninterrupted in service by $78 \%$ and only $7 \%$ of them are on the verge of collapse; but knee member in five -bay undergone buckling by $9 \%$ and lost their performance.
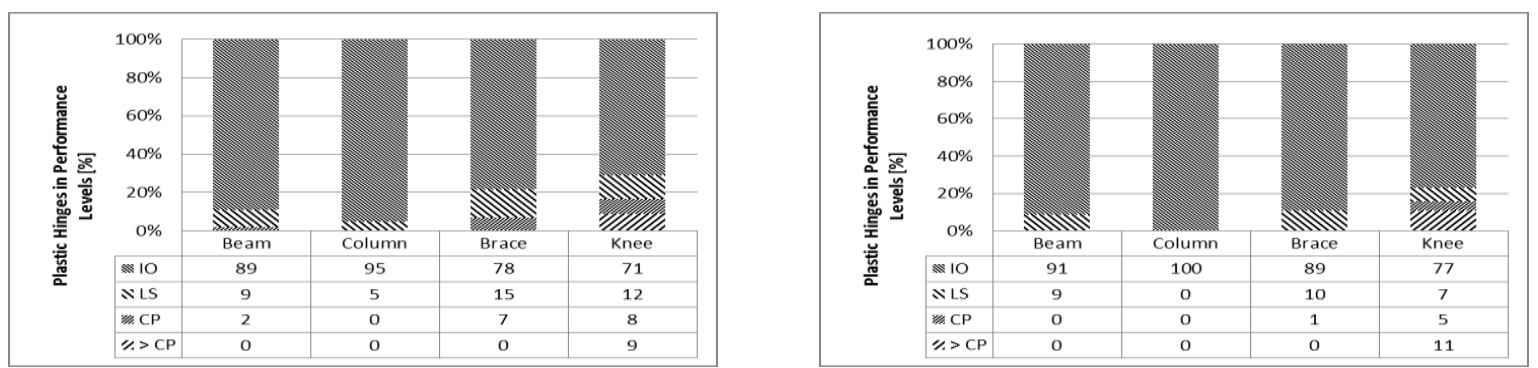

Figure 10. Performance level of five -story frame of knee bracing

Figure (11-A) show performance level of five -story,three -bay frames with Chevron bracings. In this structure, $90 \%$ of column are uninterrupted in service performance level and also $96 \%$ of beam are uninterrupted in service performance level and $4 \%$ of them are at the performance level of life safety. Bracings for three -bay bracing frames in $67 \%$ of cases are uninterrupted in service performance level and 10\% undergone destruction. But figure (11-B) shows performance level of five-story, five-bay frames with Chevron bracings. In this structure, $93 \%$ of column are uninterrupted in service performance level and $80 \%$ of bear also are uninterrupted in service performance level and $15 \%$ are at the performance level of life safety. Braces for bracing frames of five-bay are uninterrupted in service performance level in $67 \%$ of cases and $17 \%$ of them are at the performance level of life safety.
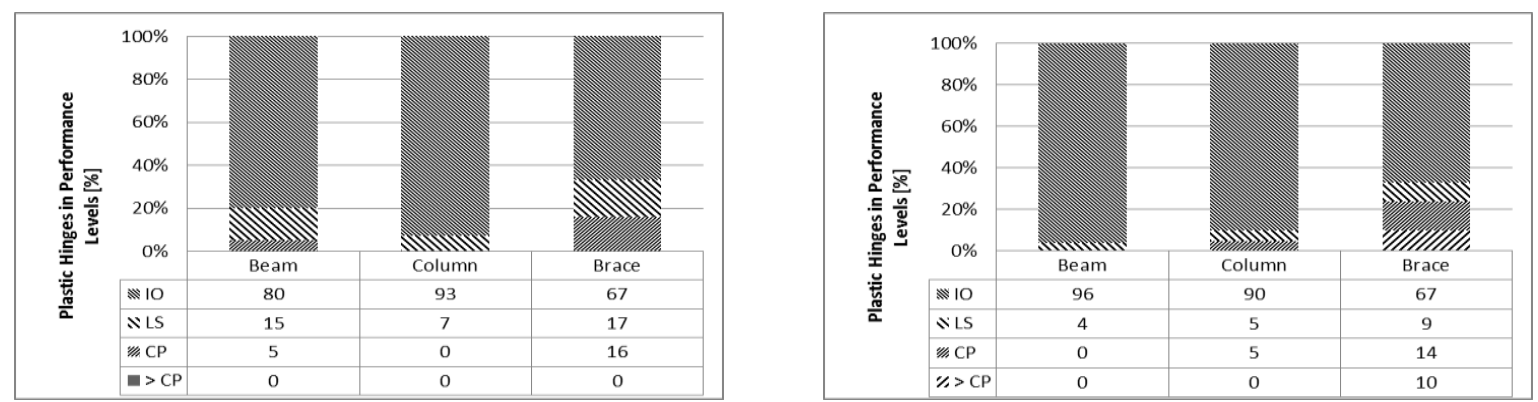
Figure 11. Performance level of five -story frame with Chevron brace

Figures (12-A) and (12-B) show performance level of five -story frames with coaxial braces. In three -bay frame, all member of column and in five -bay $93 \%$ of column are uninterrupted in service performance level but $79 \%$ of beam in three -bay frame and $74 \%$ in five -bay are at the uninterrupted service performance level. Braces for bracing frames of three -bay and for five-bay structures in 57\% of cases are at the uninterrupted service performance level and in other cases, are at the performance level of life safety.
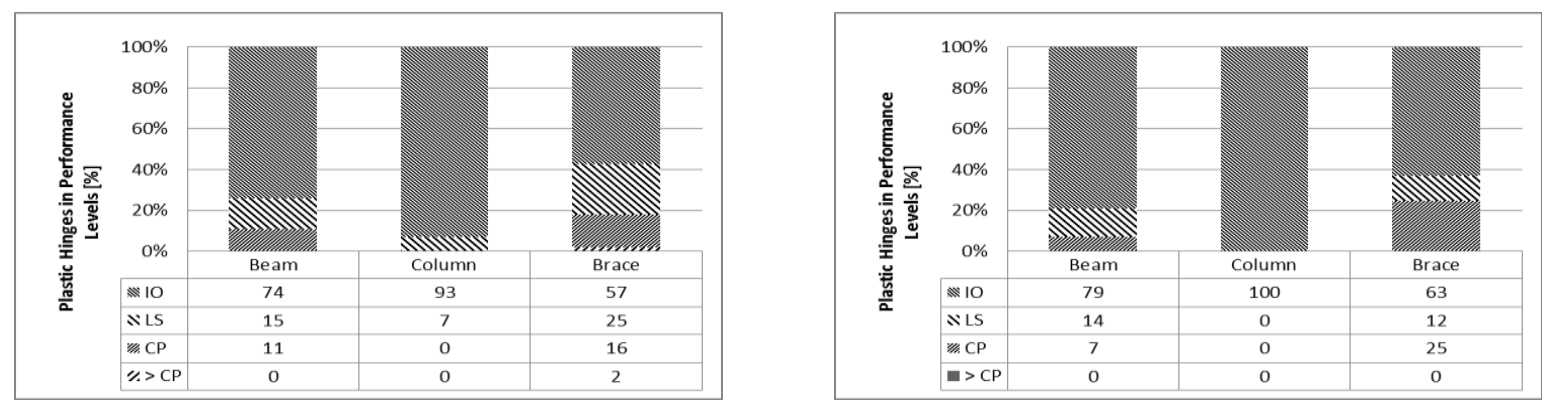

Figure 12. Performance level of five -story frame with coaxial brace

Figures (13-A) and (13-B) show performance level of moment five -story frames. In these structures of five -story three -bay, $12 \%$ of beam members, are at the performance level of life safety but $90 \%$ of three -bay and $93 \%$ of five -bay of column members -bay are at the uninterrupted service performance level.
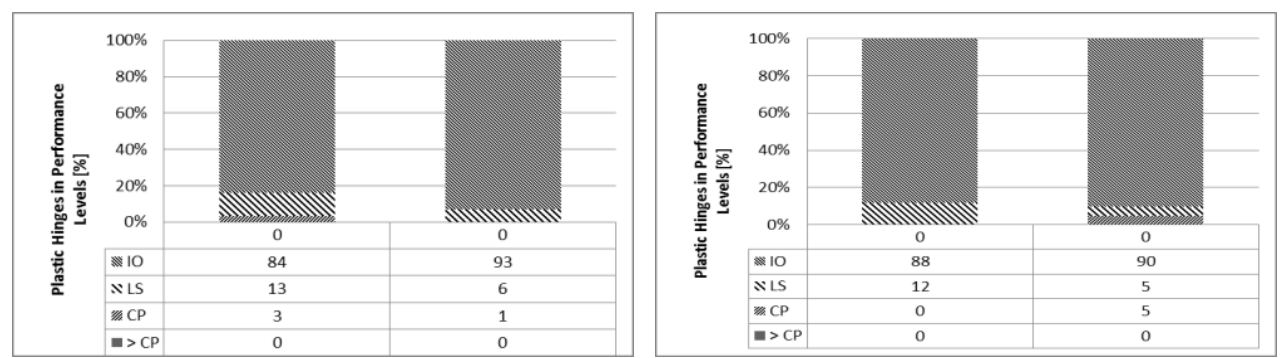

Figure 13. Performance level of moment five -story frame

Figures (14-A) and (14-B) show performance level of seven -story frame with knee braces. In three -bay structure, $90 \%$ of column members and in five -bay structure, $88 \%$ of column members are at the uninterrupted service performance level. Performance of knee members in three -bay bracing was satisfying and in addition to being stayed in life safety area, causes 50\% and five -bay being stayed at the uninterrupted service performance level by $44 \%$. However, $23 \%$ of knee member for three -bay frame and $35 \%$ for five -bay structures have suffered destruction. In three -bay, $11 \%$ of five -bay and $10 \%$ of knee members are at the performance level of collapse.
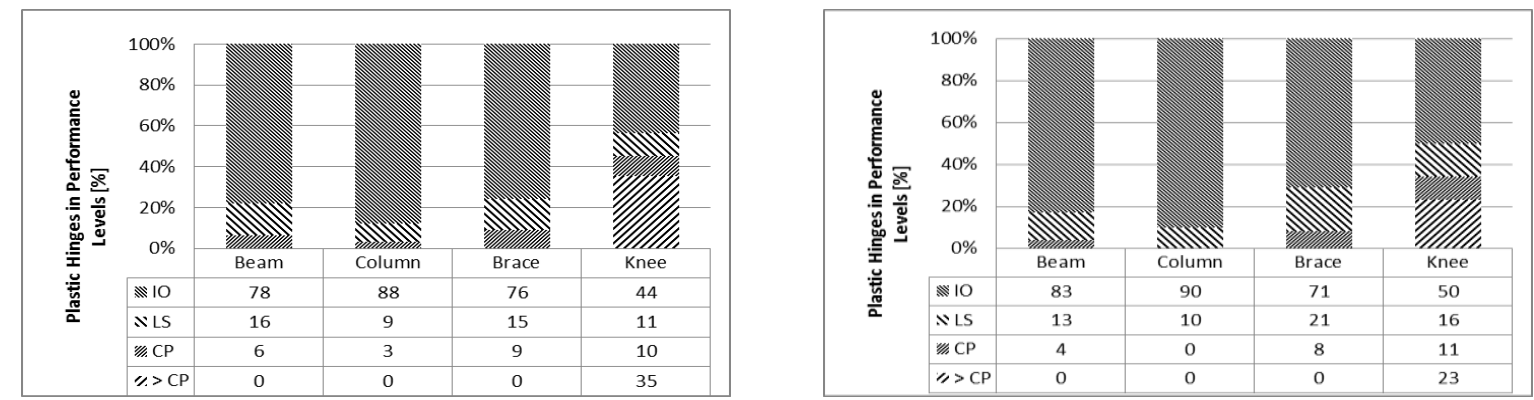


\section{Figure 14. Performance level of seven -story frame of knee brace}

Figure (15-A) shows performance level of seven -story frames with Chevron braces. In this structure, $96 \%$ of column members and $93 \%$ beam members are at the performance level of uninterrupted service, $4 \%$ of them are at the performance level of life safety and $3 \%$ of them are on the verge of collapse. $71 \%$ of braces for three -bay bracing frames are at the performance level of uninterrupted service, $7 \% \mathrm{f}$ them are on the verge of collapse and $22 \%$ lost their performance. But in figure (15-B) of five -bay frame, $91 \%$ of columns are at the performance level of uninterrupted service. But $88 \%$ beams are at the performance level of uninterrupted service and the other $6 \%$ are at the performance level of life safety , $6 \%$ are on the verge of collapse, $64 \%$ of braces are at the uninterrupted service, $5 \%$ of are on the verge of collapse that $5 \%$ of them are destructed.
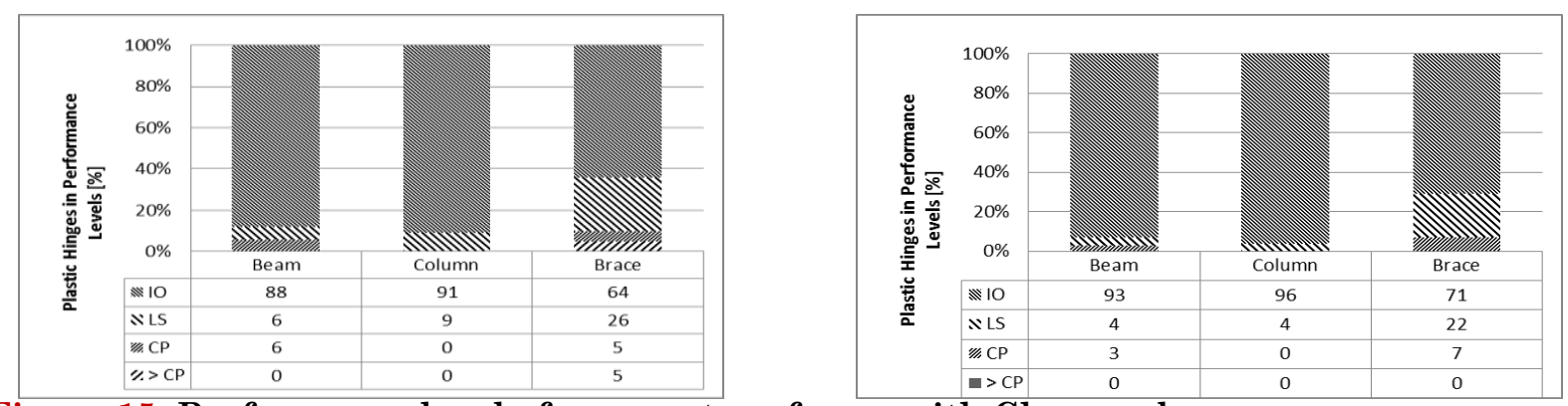

Figure 15. Performance level of seven -story frame with Chevron brace

Figures (16-A) and (16-B) shows performance level of seven -story frames with coaxial braces. In three -bay frame, $82 \%$ of column members and $79 \%$ of beam are at the performance level of uninterrupted service. 39\% of braces for three bay bracing frames and $95 \%$ of column members for five -bay structures and $84 \%$ of beam are at the performance level of uninterrupted service and only $9 \%$ of the braces in five -bay and $11 \%$ of them in three -bay lost their performance.
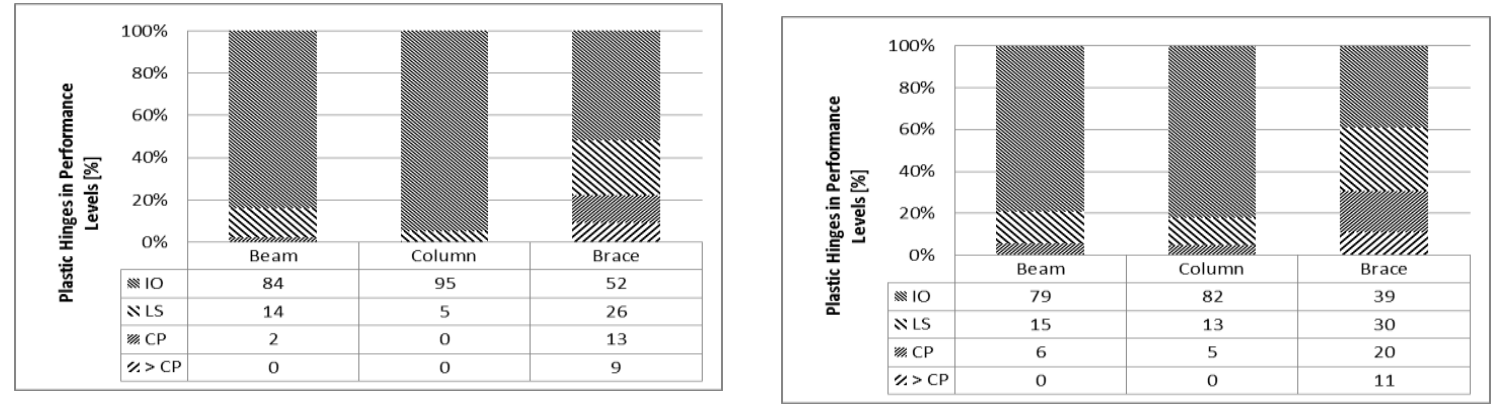

Figure 16. Performance level of seven -story frame with coaxial brace

Figures (17-A) and (A-B) show performance level of moment seven -story frames. In three -bay frame, $96 \%$ of column members and in five -bay frame, $89 \%$ of column members are at the performance level of uninterrupted service. But 
beams in three -bay, $16 \%$ are at the performance level of life safety and $78 \%$ are at the performance level of uninterrupted service and in five -bay, $18 \%$ are at the performance level of life safety and $70 \%$ are at the performance level of uninterrupted service.
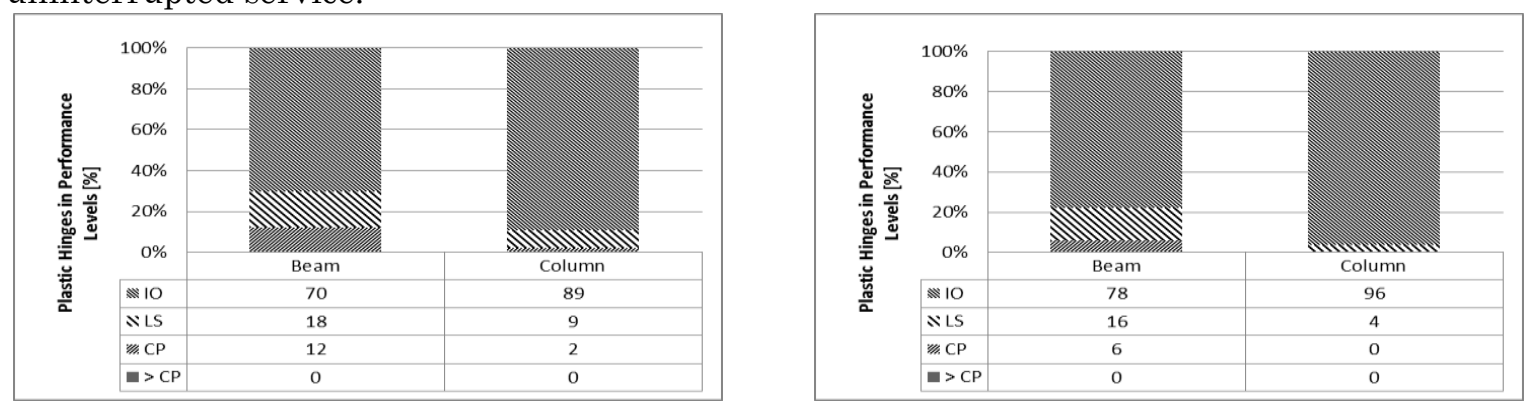

Figure 17. Performance level of moment five -story frame

Considering figures 6 to 17, it can be said that structures with knee brace have performance level of uninterrupted service with $86 \%$ in three -story three -bay, $64 \%$ in three -story five -bay, $77 \%$ in five -story three -bay, $71 \%$ in five -story five -bay, $50 \%$ in seven -story three -bay and $44 \%$ in seven -story five -bay have knee brace. While in structures with Chevron brace, performance level of uninterrupted service of three -story three -bay is $67 \%$, three -story five -bay is $73 \%$, five -story three -bay is $67 \%$, five -story five -bay is $67 \%$, seven -story three -bay $71 \%$ and seven -story and five -bay is $64 \%$ and most of beam and column members undergone buckling but in coaxial brace performance level uninterrupted service of three -story three -bay is 50\%, three -story five -bay is $49 \%$, five -story three -bay is $63 \%$, five -story five -bay is $57 \%$, seven -story three -bay is $39 \%$ and seven -story five -bay is $52 \%$. It can be concluded that structures with knee brace has better performance level than Chevron and coaxial brace.

\section{Conclusion}

For better understanding structures of knee bracing, steel frames including moment frames, knee bracing, coaxial bracing and Chevron bracing with 3,5 and 7 -story were evaluated. In this research, members performance and the base shear of steel structures was evaluated. Results show that structures of knee bracing have more power of energy absorption and ductility than the other bracing systems; as comparison done between frames and knee brace and coaxial brace, Chevron brace and moment frame, knee members causes plastic hinges being created in knee members before formation in brace member in moment form. In most of the cases, plastic hinges being formed in knee member and decrease braces destruction. Structures with knee brace under uniform load pattern experience more base shear than structures with knee brace under load pattern of vibration modulus. So, equally values of the base shear for designing knee brace is less than $\mathrm{X}$ bracing and reduce steel consumption.

1. In five -bay structures because of having more knee members, the base shear is less than three -bay which is show that the more number of knee member have more energy absorption that leads to the base shear reduction. 
Dejkam

2. Knee member in KBF frames has drastic drop after yielding because of ductile fuse formation on them. Accordingly, energy depreciation is done for forming moment plastic hinges and damages small portion of the building which can be repaired or replaced easily. So, in this sense, KBF frames are better over the similar CBF frames.

3. Structures with knee brace under uniform load pattern experience more base shear over the structures with knee brace under modulus load pattern of vibration.

4. The base shear of three -story has $8 \%$ decrease over the three -story with moment frames.

5. The base shear of three -story has $10 \%$ increase over the three -story with Chevron frame and $13 \%$ increase over the three -story with coaxial brace.

6. The base shear of five -story with knee brace has $11 \%$ decrease over the five -story with moment frame.

7. The base shear of five -story with knee brace has $11 \%$ decrease over five story with Chevron frame and $5 \%$ increase over the five -story with coaxial brace.

8. The base shear with seven -story with knee brace has $26 \%$ decrease over the seven -story with Chevron frame and has 7\% increase over then coaxial brace. Generally, the knee bracing system is a bracing system which can supply appropriate hardness and high ductility for structure if effective parameters are chosen and after earthquake, it can be reused with replacing knee member.

\section{Disclosure statement}

No potential conflict of interest was reported by the authors.

\section{Notes on contributors}

Behzad Dejkam

Faculty member of Civil Engineering University of velayat, Iranshahr, Iran.

\section{References}

Kalkan E. and Kunnath S. K. (2004), "Method of modal combinations for pushover analysis of buildings," in Proc. Of the 13 th World Conference of Earthquake Engineering.

Khatib I. F., Mahin S. A., and Pister K. S. (1988), Seismic behavior of concentrically braced steel frames vol. 88: Earthquake Engineering Research Center, University of California.

Uriz P. (2008), Toward earthquake-resistant design of concentrically braced steel-frame structures: Pacific Earthquake Engineering Research Center.

Aristizabal-Ochoa J. D. (1986), "Disposable knee bracing: improvement in seismic design of steel frames," Journal of Structural Engineering, vol. 112, pp. 1544-1552.

Roeder C. W.and Popov E. P. (1978), "Eccentrically braced steel frames for earthquakes," Journal of the Structural Division, vol. 104, pp. 391-412.

Naeemi M. and Bozorg M. (2009), "Seismic Performance of Knee Braced Frame," Proceedings of World Academy of Science: Engineering \& Technology, vol. 50,pp 976-980.

Kim J.and Seo Y. (2003), "Seismic design of steel structures with buckling-restrained knee braces," Journal of Constructional Steel Research, vol. 59, pp. 1477-1497.

Balendra T., Sam M. T., and Liaw C. Y. (1990), "Diagonal brace with ductile knee anchor for aseismic steel frame," Earthquake engineering \& structural dynamics, vol. 19, pp. 847-858.

Agency F. E. M. (2000), "Prestandard and Commentary for the Seismic Rehabilitation of Buildings: FEMA-356," ed: Federal Emergency Management Agency Washington.

Code U. B. (1997), "UBC 97, Code for Seismic Design of Buildings (1997 Edition)," Structural Engineering Design Provisions, vol. 2.

Balendra T., Sam M.-T., Liaw C.-Y., and Lee S.-L. (1991), "Preliminary studies into the behaviour of 
knee braced frames subject to seismic loading ",Engineering Structures, vol. 13, pp. 67-74.

FEMA A. (2005), "440, Improvement of nonlinear static seismic analysis procedures," ed: Federal Emergency Management Agency, Washington DC.

Elnashai A. S. (2001), "Advanced inelastic static (pushover) analysis for earthquake applications," Structural engineering and mechanics, vol. 12, pp. 51-70.

Krawinkler H.and Seneviratna G. (1998), "Pros and cons of a pushover analysis of seismic performance evaluation," Engineering Structures, vol. 20, pp. 452-464

Chopra A. K.and Goel R. K. (2002), "A modal pushover analysis procedure for estimating seismic demands for buildings," Earthquake engineering \& structural dynamics, vol. 31, pp. 561-582.

Chopra A. K., Goel R. K., and Chintanapakdee C. (2004), "Evaluation of a modified MPA procedure assuming higher modes as elastic to estimate seismic demands," Earthquake Spectra, vol. 20, pp. 757-778.

Ghodrati,A and Eghbali,M (2011)"New method of two line pushover for seismic evaluation of steel frames. 5th natinal congress of construction engineering. Mashhad. 